\title{
THE INFLUENCE OF STRIP CROPPING AND WEED CONTROL METHODS ON WEED DIVERSITY IN DENT MAIZE (Zea mays L.), NARROW-LEAFED LUPIN (Lupinus angustifolius L.) AND OATS (Avena sativa L.)
}

\author{
Aleksandra Głowacka \\ University of Life Sciences in Lublin, Faculty of Agricultural Sciences in Zamość \\ Szczebrzeska 102, 22-400 Zamość, Poland \\ e-mail: aleksandra.glowacka@up.lublin.pl
}

Received: 11.09.2012

\begin{abstract}
The experiment was conducted in 2008-2010 at the Experimental Station of the Faculty of Agricultural Sciences in Zamość, University of Life Sciences in Lublin. The research design included two factors: I. Method of cultivation - sole cropping and strip cropping (the cultivation of three plants: maize, narrow-leafed lupin and oats, in neighboring strips); II. Weed control method - mechanical and chemical. The subject of this study was weed infestation in maize, narrow-leafed lupin and oats.

The greatest diversity of weeds was found in the narrow-leafed lupine crop, while the lowest diversity in maize. The dominant weed species in maize, lupine and oats were Echinochloa crus-galli, Chenopodium album and Galinsoga parviflora which ranged from $34 \%$ to $99 \%$ of the total number of weeds. Strip cropping clearly reduced the number of weeds per unit area in the narrow-leafed lupin and oat crops as well as the aboveground dry weight of weeds in all plant species. Chemical weed control significantly decreased both the number and weight of weeds in comparison with the mechanical method.
\end{abstract}

Key words: strip cropping, weed infestation, Avena sativa L., Lupinus angustifolius L., Zea mays L.

\section{INTRODUCTION}

Biodiversity in agrosystems plays an important role in providing ecological functions such as nutrient cycling, pest control or microclimate regulation [1]. Intensification of agriculture causes genetic uniformity of crops as well as reduced spatial and temporal variation of land use and simplifies the structure of the landscape [2]. Therefore, the idea of sustainable management is promoted, taking into account the high level of production and reducing the negative impact on the environment. It is recommended to use proper crop rotation and intercropping to increase species diversity in fields. Strip cropping is a form of intercropping. It involves growing two or more species of plants in strips wide enough to allow independent mechanical cultivation, yet narrow enough for the interaction of plants in adjacent strips. Placing the plants in separate strips causes the competition between them to be minimized and yield increases especially in the edge rows of a strip [3]. Less competition from pests and diseases gives the possibility to reduce pesticide use [4]. Strip cropping can affect weed infestation in plants. The studies conducted in Poland found that this system had an effect on reducing the density and biomass of weeds in a bean crop, while in maize only the number of weeds was reduced. Both in the bean and maize crops, the beneficial effect of strip cropping was particularly significant under mechanical weed control $[5,6]$. The effectiveness of strip cropping was dependent of crop species, the width of the strips and the weather conditions during the growing season $[7,8]$. The aim of this study was to evaluate the impact of cropping method (sole cropping and strip cropping) in combination with various methods of weed control (mechanical and chemical) on the state and degree of weed infestation in dent maize, narrow-leafed lupin and oats.

\section{MATERIALS AND METHODS}

The field experiment was carried out in 20082010 at the Experimental Station of the Faculty of Agricultural Sciences in Zamość, University of Life 
Sciences in Lublin $\left(50^{\circ} 42^{\prime} \mathrm{N}, 23^{\circ} 16^{\prime} \mathrm{E}\right)$, on brown soil, slightly acidic $\left(\mathrm{pH}_{\mathrm{KCl}}-6.0\right)$, with medium humus

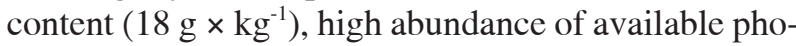
sphorus and potassium $\left(175 \mathrm{mg} \times \mathrm{P} \mathrm{kg}^{-1}\right.$ and $206 \mathrm{mg}$ $\mathrm{K} \times \mathrm{kg}^{-1}$ ) and a medium level of available magnesium $\left(57 \mathrm{mg} \mathrm{Mg} \times \mathrm{kg}^{-1}\right)$. The experiment was set up as a split-plot design, with four replications. The subject of the research was weed infestation of the 'Celio' variety of dent maize, the 'Sonet' variety of narrow-leafed lupin, and the 'Kasztan' variety of oats. The following factors were examined in the experiment: I. Cropping method (CM): 1 . Sole cropping, in which the size of one plot of each crop plant was $26.4 \mathrm{~m}^{2}$; 2. Strip cropping, in which three crops - dent maize (Zea mays L.), narrow-leafed lupin (Lupinus angustifolius L.) and oats (Avena sativa L.) - were grown side by side, each in a separate $3.3 \mathrm{~m}$ wide strip. The size of the plots was $13.2 \mathrm{~m}^{2}$ each. II. Method of weed control: A - Mechanical: maize - weeding of interrows twice (first at the 5-6 leaf stage - BBCH 15-16-and again two weeks later); narrow-leafed lupin - harrowing twice (first after sowing, pre-emergence - $\mathrm{BBCH} 00-01$, then after emergence, before the plant reached a height of $5 \mathrm{~cm}-\mathrm{BBCH} 13-15$ ); oats - harrowing twice (first at the 1-leaf stage $(\mathrm{BBCH} 10)$, then at the 5-leaf stage $(\mathrm{BBCH} 15) ; \mathrm{B}$ - chemical herbicides: maize - a.i. bromoxynil + terbuthylazine at $144 \mathrm{~g} \times \mathrm{ha}^{-1}+400 \mathrm{~g}$ $\times$ ha $^{-1}$ at the 4-6 leaf stage (BBCH 14/16); narrow-leafed lupin - a.i. linuron directly after sowing at $675 \mathrm{~g} \times$ $\mathrm{ha}^{-1}+$ a.i. metamitron at $2,800 \mathrm{~g} \times \mathrm{ha}^{-1}$ after emergence, at the 2-3 leaf stage (BBCH 12/13); spring oats - a.i. 4-chloro-2-methylphenoxyacetic acid at $550 \mathrm{~g} \times \mathrm{ha}^{-1}$ at the full tillering stage (BBCH 22/23).

\section{Agricultural procedures}

Maize was grown on a site where the previous crop had been oats. Mineral fertilization was applied uniformly at rates of N 140, P 35, and K $100 \mathrm{~kg} \times \mathrm{ha}^{-1}$. Phosphorus and potassium fertilizers were applied once before pre-sowing treatments, and nitrogen was applied in split applications (half before sowing, and the remainder at the stage 14/15 BBCH). In the successive years, maize was sown on 28 April as well as on 2 and 5 May. The sowing rate was 110,000 seeds per hectare, and the spacing between rows was $65 \mathrm{~cm}$. In sole cropping, 10 rows of maize were planted in the plot, while in strip cropping 5 rows were planted. The maize was harvested at the milk-dough stage- BBCH 79/83.

Narrow-leafed lupin was grown on a site were the previous crop had been maize. Mineral fertilizers were applied uniformly at rates of N 20, P 26, and $\mathrm{K} 99 \mathrm{~kg} \times \mathrm{ha}^{-1}$. All fertilizers were applied once before sowing. Seeding rate was $180 \mathrm{~kg} \times \mathrm{ha}^{-1}$. The seeds were treated with Vitavax 200 FS (a.i. carboxin $200 \mathrm{~g}$ $\times \mathrm{dm}^{-3}+$ thiram $200 \mathrm{~g} \times \mathrm{dm}^{-3}$ ) before sowing. Lupin was grown for seeds and harvested at $\mathrm{BBCH} 89$ in the second or third 10-day period of August.

Oats were grown on a site were the previous crop had been narrow-leafed lupin. Mineral fertilizers were applied uniformly at rates of N 60, P 22, and $\mathrm{K} 110 \mathrm{~kg} \times \mathrm{ha}^{-1}$. All nutrients were applied once before sowing. In successive years of the study, oats were sown at the same time as narrow-leafed lupin at a rate of $180 \mathrm{~kg} \times \mathrm{ha}^{-1}$. Before sowing, the seeds were mixed with the Zaprawa Nasienna T 75 DS/WS seed dressing (a.i. thiram $75 \%$ ). Oats were harvested in the first or second 10-day period of August (BBCH 89).

In each of the crops grown in the experiment, the herbicides were applied with a Pilmet Sano 2 P-030 backpack sprayer. Mineral fertilizers were applied in following forms: $\mathrm{N}$ - ammonium nitrate, $\mathrm{P}$ - triple superphosphate, $\mathrm{K}$ - potassium salt.

Weather conditions varied over the study period. Rainfall was lowest in 2009 and it was lower than the long-term average. Moreover, rainfall was unevenly distributed over the years. A severe shortage of precipitation occurred in April and July, while heavy rainfall was recorded in May and June. In the years 2008 and 2010, rainfall was much higher and exceeded the long-term average by $56.4-61.8 \mathrm{~mm}$. The average monthly temperatures for each year were higher than the long-term average.

Weed infestation of the crops was assessed two weeks before harvesting by determining the species composition, number and dry weight of weeds. In each plot, two random sample areas were marked off with a $1 \mathrm{~m} \times 0.5 \mathrm{~m}$ frame. Within each frame, individual weed plants were counted and the floristic composition was determined. When the weeds had been extracted and their roots cut off, the plants were dried and weighed to determine the air-dry weight of individual species and the total weight of weeds. Species nomenclature followed Mirek et al. [9]. The results were analysed statistically using variance analysis. The differences between means were evaluated with Tukey's test. The results were tested at a probability of $95 \%$.

\section{RESULTS}

\section{Zea mays $\mathbf{L}$.}

Twenty species were recorded in the maize crop. Of the five monocot taxa, Echinochloa crus-galli occurred frequently, while Setaria pumila, Setaria viridis, Avena fatua and Elymus repens sporadically. Despite the small number of species, monocots accounted for $24.5 \%$ to $45.3 \%$ of the total number of weeds (Table 1). Neither cropping systems nor weed control methods significantly affected weed species diversity in the maize crop. Irrespective of the experimental 
factors, Galinsoga parviflora, Echinochloa crus-galli and Chenopodium album were the dominant species, accounting for $99.0 \%$ and $70.8 \%$ of the total number of weeds in sole cropping, and for $82 \%$ and $47.6 \%$ in strip cropping, for mechanical and chemical weed control, respectively. Polygonum lapathifolium, Galinsoga ciliata, Veronica arvensis and Polygonum convolvulus were frequent, as well. Galinsoga parviflora, Echinochloa crus-galli and Chenopodium album were dominant due to their high biomass, especially where mechanical weed control was used (Fig. 1). There were no significant differences in the number of weeds per unit area of maize between strip cropping and sole cropping (Table 2). Aboveground biomass of weeds was significantly lower in strip cropping, by an average of $16 \%$. The weed control methods significantly affected weed density in maize. On average in the experiment, the number of weeds in the plots with herbicides was 2.5 times lower than in the mechanically weeded plots. In maize, chemical weed control reduced the occurrence of Galinsoga parviflora by 85\%, Echinochloa crus-galli by $56.6 \%$ and Chenopodium album by $75.4 \%$. The effect of weed control method on reducing the dry weight of weeds was significant in each year of the study. On average for the study, the dry weight of weeds in the mechanically weeded plots was 3 times greater than in the treatment where herbicides were used. There was no significant interaction between cropping system and weed control method in determining changes in weed infestation indicators in maize.

\section{Lupinus angustifolius $\mathbf{L}$.}

Irrespective of the experimental factors, the most frequently occurring species in the narrow-leafed lupin crop were Chenopodium album, Echinochloa crus-galli and Galinsoga parviflora (Table 3), accounting for $74.9 \%$ and $47.8 \%$ of the total number of weeds in sole cropping as well as for $65.4 \%$ and $34.1 \%$ in strip cropping, for the mechanical and chemical weed control methods, respectively. The next most frequent taxa were Galium aparine, Polygonum lapathifolium, Setaria pumila, and Melandrium album. Other species were rare or sporadic. Overall, 26 weed species were recorded in the lupin crop -4 perennials and 22 ephemerals. Only 5 of the 26 taxa were monocots, but their share in the total number of weeds was relatively large $-21.5-34.8 \%$. The cropping systems did not affect weed species diversity in lupin. Chemical weed control increased the number of species in the lupine crop (Table 3 ). The herbicides significantly reduced the number of Chenopodium album and $\mathrm{Ga}$ linsoga parviflora. Strip cropping reduced the number of weeds per unit area, by $6 \%$ on average. The impact of the cropping system on weed biomass was much stronger. Strip cropping reduced the aboveground dry weight of weeds by $28.8 \%$ on average in relation to sole cropping. The study also confirmed a significant interaction between cropping systems and weed control methods. In the mechanically weeded plots, strip cropping reduced the number of weeds by $14 \%$ and their aboveground weight by $37.6 \%$. Where chemical weed control was used, the differences between both the number and biomass of weeds were not significant. The weed control methods significantly affected the weed infestation indicators in lupin. On average for the experiment, chemical weed control reduced the number of weeds by $37.2 \%$ and their biomass by $52.7 \%$ compared to the mechanical treatment (Table 4). The use of herbicides strongly reduced both the frequency and biomass of Chenopodium album and Galinsoga parviflora (Table 3, Fig. 2).

\section{Avena sativa $\mathrm{L}$.}

In the oat crop, 25 weed species occurred 21 ephemerals and 4 perennials (Table 5). The most frequent species was Chenopodium album. Its percentage in the total number of weeds was $38.3 \%$ and $19.3 \%$ in sole cropping as well as $40.2 \%$ and $22.7 \%$ in strip cropping, for mechanical and chemical weed control, respectively. Chenopodium album also produced a large amount of dry matter, especially in the mechanically weeded plots (Fig. 3). Galinsoga parviflora and Echinochloa crus-galli were also common. The next most frequent species were Melandrium album, Setaria pumila, and Lapsana communis. The cropping system did not affect weed species diversity in oats. The weed control methods influenced the number of species in the oats crop. The effect of strip cropping on the number of weeds varied in different years of the study. However, on average for the experiment, strip cropping significantly decreased weed density. Strip cropping significantly reduced the dry weight of weeds in the oat crop, by $23.8 \%$ on average. Herbicide use significantly decreased the total number of weeds, by $53.2 \%$ on average, while weed biomass by $68.3 \%$, compared to mechanical weed control. The herbicides strongly reduced both the number and biomass of Chenopodium album (Table 5, Fig. 3). There was no significant interaction between cropping systems and weed control methods (Table 6). 


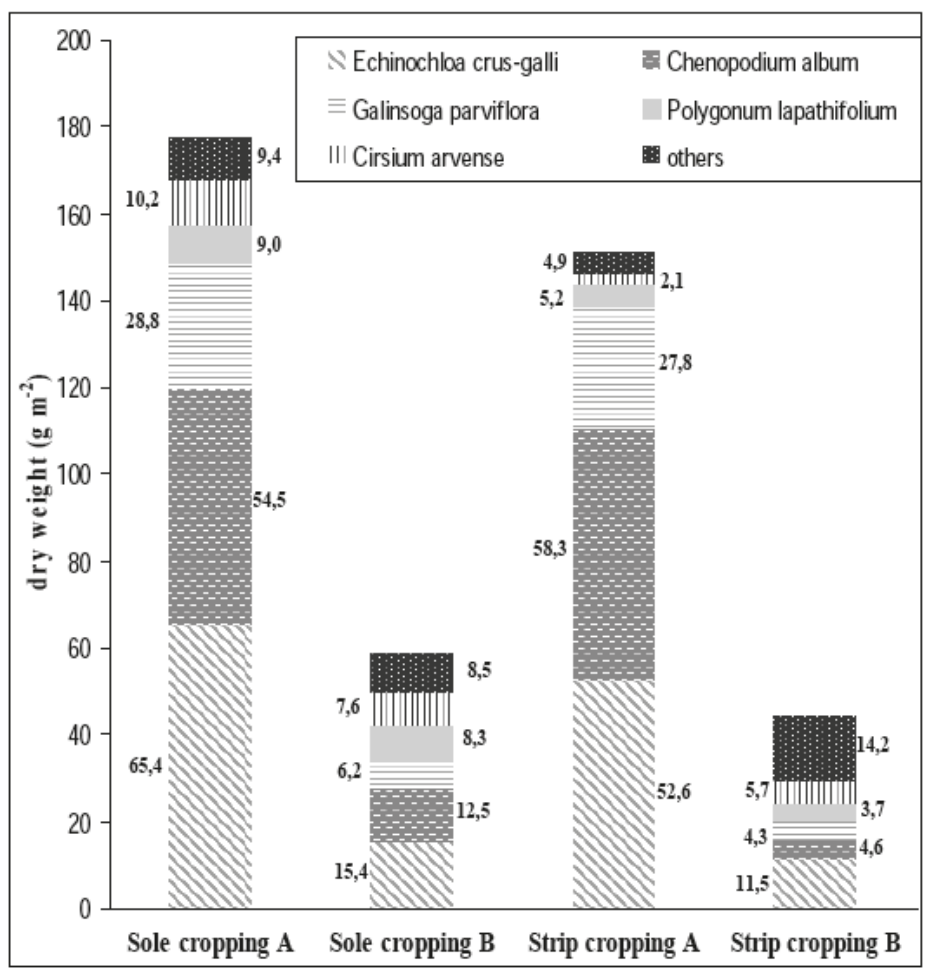

Fig. 1. Air-dry weight of aboveground parts of weeds species in maize canopy (mean for 2008-2010).

Table 1

Species composition and number of weeds per $1 \mathrm{~m}^{2}$ of maize crop before harvest, depending on the cropping system (mean for 2008-2010 years)

\begin{tabular}{|c|c|c|c|c|c|c|}
\hline \multirow{2}{*}{ Species composition } & \multicolumn{3}{|c|}{ Sole cropping } & \multicolumn{3}{|c|}{ Strip cropping } \\
\hline & A & $\mathrm{B}$ & mean & A & $\mathrm{B}$ & mean \\
\hline \multicolumn{7}{|c|}{ Short lived } \\
\hline Echinochloa crus-galli (L) P. Beauv & 13.8 & 5.5 & 9.7 & 7.4 & 3.7 & 5.9 \\
\hline Chenopodium album $\mathrm{L}$ & 5.8 & 1.3 & 3.6 & 7.1 & 1.8 & 4.5 \\
\hline Galinsoga parviflora Cav. & 18.1 & 2.9 & 10.5 & 12.0 & 1.5 & 6.8 \\
\hline Capsella bursa-pastoris (L.) Medik. & 0.2 & - & 0.1 & 0.5 & - & 0.3 \\
\hline Galium aparine $\mathrm{L}$. & - & 0.3 & 0.2 & 0.2 & 0.5 & 0.4 \\
\hline Avena fatua $\mathrm{L}$. & - & - & - & 0.2 & - & 0.1 \\
\hline Polygonum lapathifolium L. subsp. lapathifolium. & 1.0 & 0.8 & 0.9 & 0.3 & 0.4 & 0.3 \\
\hline Setaria pumila (Poir) Roem. \& Schult & 0.5 & 0.2 & 0.4 & 0.3 & 1.4 & 0.8 \\
\hline Melandrium album (Mill.) Gracke & 0.2 & - & 0.1 & - & - & - \\
\hline Vicia hirsuta $\mathrm{L}$. & - & 0.4 & 0.2 & - & 0.3 & 0.2 \\
\hline Polygonum convolvulus L. & 0.2 & 0.4 & 0.3 & 0.3 & 0.6 & 0.5 \\
\hline Veronica arvensis $\mathrm{L}$. & 0.6 & 0.9 & 0.8 & 0.3 & 0.9 & 0.6 \\
\hline Lapsana communis $\mathrm{L}$. & - & 0.2 & 0.1 & - & - & - \\
\hline Setaria viridis (L.) P. Bauer. & - & 0.3 & 0.1 & - & 0.3 & 0.1 \\
\hline Galinsoga ciliata $\mathrm{L}$. & 1.3 & 0.2 & 0.8 & 0.4 & 1.4 & 0.9 \\
\hline Sonchus oleraceus L. & - & 0.3 & 0.2 & - & - & - \\
\hline Geranium pusillum $\mathrm{L}$. & - & 0.2 & & 0.1 & 0.1 & 0.1 \\
\hline Total of short-lived species & 10 & 14 & 15 & 12 & 12 & 14 \\
\hline \multicolumn{7}{|c|}{ Perennial } \\
\hline Equisetum arvense $\mathrm{L}$. & - & - & - & - & 0.7 & 0.4 \\
\hline Cirsium arvense (L.) Scop. & 1.3 & 1.9 & 1.6 & 1.2 & 1.1 & 1.1 \\
\hline Elymus repens (L.) Gould & - & 0.2 & 0.1 & - & 0.2 & 0.1 \\
\hline Number of perennial species & 1 & 2 & 2 & 1 & 3 & 3 \\
\hline
\end{tabular}

Weed control: A - mechanical, B - chemical 
Table 2

Weed density and air-dry weight of weeds in the maize crop

\begin{tabular}{|c|c|c|c|c|c|c|c|c|c|}
\hline \multirow{3}{*}{$\begin{array}{l}\text { I. Method of } \\
\text { cultivation }\end{array}$} & \multirow{3}{*}{$\begin{array}{l}\text { II. Weed } \\
\text { control }\end{array}$} & \multicolumn{4}{|c|}{ Weed density (per $1 \mathrm{~m}^{2}$ ) } & \multicolumn{4}{|c|}{ Air-dry weight $\left(\mathrm{g} \times \mathrm{m}^{-2}\right)$} \\
\hline & & \multicolumn{3}{|c|}{ Years } & \multirow{2}{*}{ Average } & \multicolumn{3}{|c|}{ Years } & \multirow{2}{*}{ Average } \\
\hline & & 2008 & 2009 & 2010 & & 2008 & 2009 & 2010 & \\
\hline SOLE CROPPING & $\begin{array}{c}\mathrm{A}^{*} \\
\mathrm{~B}\end{array}$ & $\begin{array}{l}16.4 \\
11.2\end{array}$ & $\begin{array}{l}44.0 \\
11.5\end{array}$ & $\begin{array}{l}53.1 \\
18.5\end{array}$ & $\begin{array}{l}37.8 \\
13.7\end{array}$ & $\begin{array}{l}177.1 \\
62.6\end{array}$ & $\begin{array}{l}135.7 \\
53.7\end{array}$ & $\begin{array}{l}207.2 \\
59.1\end{array}$ & $\begin{array}{l}177.3 \\
58.5\end{array}$ \\
\hline Strip cropping & $\begin{array}{l}\mathrm{A} \\
\mathrm{B}\end{array}$ & $\begin{array}{l}17.6 \\
11.7\end{array}$ & $\begin{array}{l}43.5 \\
13.5\end{array}$ & $\begin{array}{l}35.8 \\
19.0\end{array}$ & $\begin{array}{l}32.3 \\
14.7\end{array}$ & $\begin{array}{l}145.0 \\
55.5\end{array}$ & $\begin{array}{c}139.9 \\
28.0\end{array}$ & $\begin{array}{c}187.5 \\
53.8\end{array}$ & $\begin{array}{l}150.9 \\
44.0\end{array}$ \\
\hline $\operatorname{LSD}(a=0.05)$ for & & n.s & n.s. & n.s. & n.s. & n.s. & n.s. & n.s. & n.s. \\
\hline \multicolumn{10}{|c|}{ Average for factors } \\
\hline SOLE CROPPING & - & 13.8 & 27.8 & 35.8 & 25.8 & 119.9 & 94.7 & 133.1 & 115.9 \\
\hline Strip cropping & - & 14.7 & 28.5 & 27.4 & 23.5 & 100.2 & 83.9 & 108.1 & 97.4 \\
\hline $\operatorname{LSD}(a=0.05)$ for & & n.s & n.s. & 7.42 & n.s. & 19.57 & n.s. & 25.02 & 14.05 \\
\hline- & A & 17.0 & 43.7 & 44.4 & 35.0 & `61.1 & 137.8 & 187.5 & 162.1 \\
\hline - & B & 11.5 & 12.5 & 18.7 & 14.2 & 59.1 & 40.8 & 53.8 & 51.2 \\
\hline $\operatorname{LSD}(a=0.05)$ for & & 2.15 & 10.41 & 5.70 & 4.90 & n.s. & 19.10 & 19.20 & 10.8 \\
\hline
\end{tabular}

Weed control: A - mechanical, B - chemical

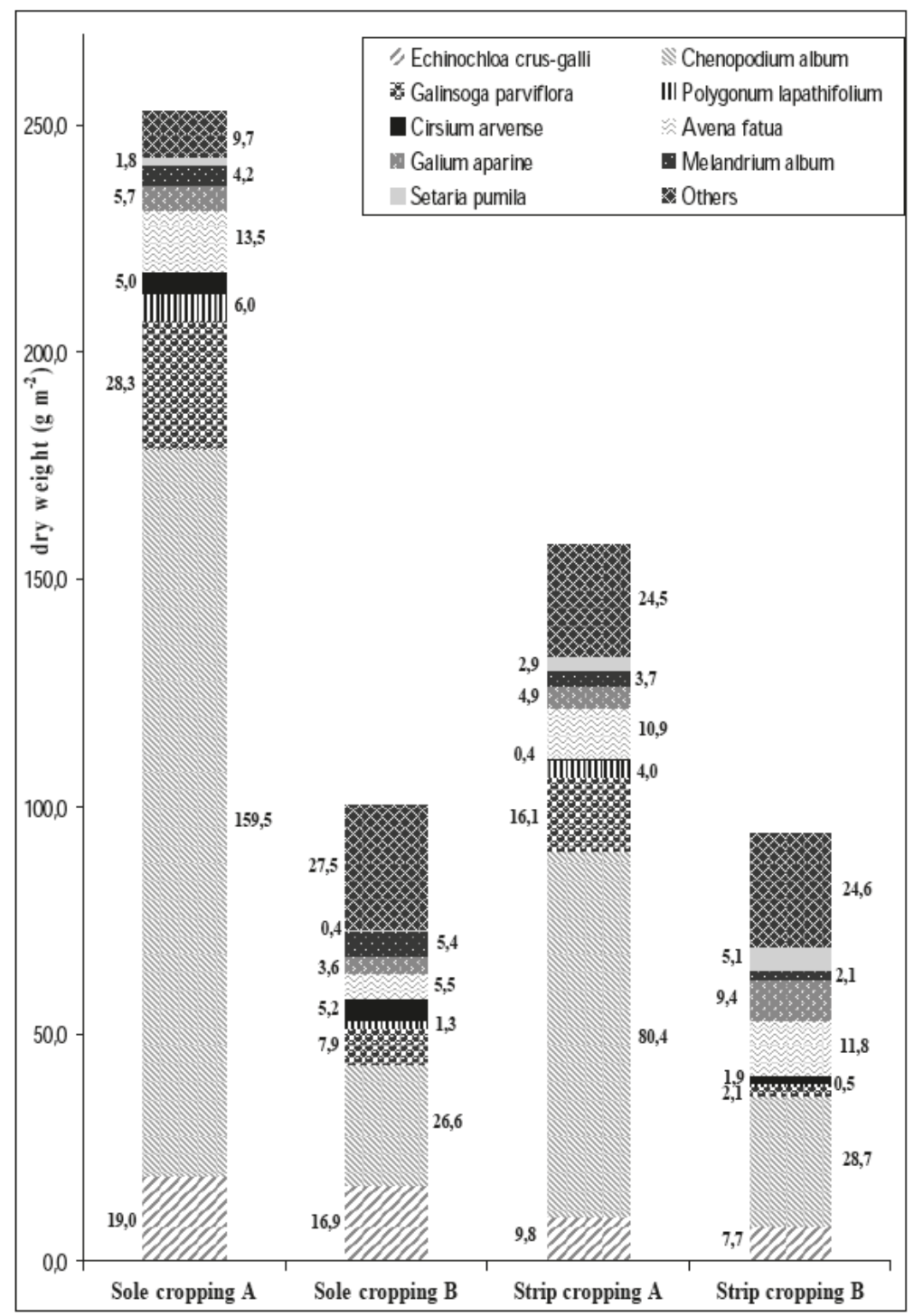

Fig. 2. Air-dry weight of aboveground parts of weeds species in narrow-leafed lupin canopy (mean for 2008-2010). 
Table 3

Species composition and number of weeds per $1 \mathrm{~m}^{2}$ of narrow-leafed lupin crop before harvest, depending on the cropping system (mean for 2008-2010 years)

\begin{tabular}{|c|c|c|c|c|c|c|}
\hline \multirow{2}{*}{ Species composition } & \multicolumn{3}{|c|}{ Sole cropping } & \multicolumn{3}{|c|}{ Strip cropping } \\
\hline & $\mathrm{A}^{*}$ & $\mathrm{~B}$ & Mean & A & $\mathrm{B}$ & Mean \\
\hline \multicolumn{7}{|c|}{ Short lived } \\
\hline Echinochloa crus-galli (L) P. Beauv & 14.3 & 9.5 & 11.9 & 10.2 & 6.6 & 8.4 \\
\hline Chenopodium album $\mathrm{L}$. & 37.8 & 10.5 & 24.2 & 31.7 & 9.5 & 20.6 \\
\hline Galinsoga parviflora Cav. & 12.4 & 3.4 & 7.9 & 6.5 & 2.0 & 4.3 \\
\hline Capsella bursa-pastoris (L.) Medik. & 2.0 & - & 1.0 & 1.6 & 1.3 & 1,5 \\
\hline Galium aparine $\mathrm{L}$. & 2.4 & 2.7 & 2.6 & 2.7 & 3.1 & 2.9 \\
\hline Stellaria media (L.) Vill. & 0.7 & 1.0 & 0.8 & 1.2 & 1.0 & 1.1 \\
\hline Polygonum lapathifolium L. subsp. lapathifolium & 1.8 & 0.6 & 1.2 & 1.0 & 0.3 & 0.7 \\
\hline Setaria pumila (Poir) Roem. \& Schult & 1.3 & 5.9 & 3.6 & 3.0 & 0.7 & 0.5 \\
\hline Melandrium album (Mill.) Gracke & 1.7 & 2.3 & 2.0 & 2.4 & 1.0 & 1.7 \\
\hline Thlaspi arvense $\mathrm{L}$ & 0.6 & 0.3 & 0.5 & 0.7 & 1.3 & 1.0 \\
\hline Lapsana communis $\mathrm{L}$. & 1.0 & 0.4 & 0.7 & 2.3 & 0.3 & 1.3 \\
\hline Polygonum convolvulus L. & 1.7 & 2.0 & 1.9 & 2.1 & 1.4 & 1.7 \\
\hline Vicia tetrasperma $\mathrm{L}$. & 1.3 & 1.0 & 1.1 & 1.0 & 1.4 & 1.2 \\
\hline Vicia hirsuta (L.) Gray., & 0.6 & - & 0.3 & 0.3 & 1.4 & 0.9 \\
\hline Matricaria maritima subsp. inodora (L.) Dostal & 1.1 & 2.6 & 1.9 & 1.0 & - & 0.5 \\
\hline Veronica arvensis $\mathrm{L}$. & 2.0 & 0.3 & 1.1 & 2.0 & - & 1.0 \\
\hline Avena fatua $\mathrm{L}$. & 4.5 & 1.6 & 3.1 & 2.7 & 6.7 & 4.7 \\
\hline Galinsoga ciliata $\mathrm{L}$. & 0.7 & 0.3 & 0.5 & 0.8 & 0.2 & 1.4 \\
\hline Viola arvensis Murray & - & 3.7 & 1.9 & 4.2 & 5.6 & 4.9 \\
\hline Galeopsis tetrahit $\mathrm{L}$. & - & - & - & - & 1.0 & 0.5 \\
\hline Apera spica venti $\mathrm{L}$. & 0.4 & - & 0.2 & - & - & - \\
\hline Papaver rhoeas $\mathrm{L}$. & - & 0.3 & 0.2 & - & - & - \\
\hline Polygonum persicaria L. & - & 0.4 & 0.2 & - & - & - \\
\hline Total of short-lived species & 19 & 19 & 22 & 19 & 18 & 20 \\
\hline \multicolumn{7}{|c|}{ Perennial } \\
\hline Equisetum arvense $\mathrm{L}$. & - & - & - & - & 5.0 & 2.5 \\
\hline Cirsium arvense $\mathrm{L}$. & 1.3 & 1.0 & 1.2 & 0.3 & 1.1 & 0.7 \\
\hline Elymus repens (L.) Gould & - & - & - & - & 1.0 & 0.5 \\
\hline Total of perennial species & 1 & 1 & 1 & 1 & 3 & 3 \\
\hline
\end{tabular}

*Weed control: A - mechanical, B - chemical

Table 4

Weed density and air-dry weight of weeds in the narrow-leafed lupine

\begin{tabular}{|c|c|c|c|c|c|c|c|c|c|}
\hline \multirow{3}{*}{$\begin{array}{l}\text { I. Method of } \\
\text { cultivation }\end{array}$} & \multirow{3}{*}{$\begin{array}{l}\text { II. Weed } \\
\text { control }\end{array}$} & \multicolumn{4}{|c|}{ Weed density (per $1 \mathrm{~m}^{2}$ ) } & \multicolumn{4}{|c|}{ Air-dry weight $\left(\mathrm{g} \times \mathrm{m}^{-2}\right)$} \\
\hline & & \multicolumn{3}{|c|}{ Years } & \multirow{2}{*}{ Average } & \multicolumn{3}{|c|}{ Years } & \multirow{2}{*}{ Average } \\
\hline & & 2008 & 2009 & 2010 & & 2008 & 2009 & 2010 & \\
\hline SOLE CROPPING & $\begin{array}{c}\text { A* }^{*} \\
\text { B }\end{array}$ & $\begin{array}{l}70.1 \\
35.9\end{array}$ & $\begin{array}{c}108.1 \\
68.0\end{array}$ & $\begin{array}{l}80.1 \\
42.8\end{array}$ & $\begin{array}{l}86.1 \\
48.9\end{array}$ & $\begin{array}{c}230.5 \\
96.0\end{array}$ & $\begin{array}{c}284.3 \\
97.9\end{array}$ & $\begin{array}{l}243.3 \\
107.1\end{array}$ & $\begin{array}{l}252.7 \\
100.3\end{array}$ \\
\hline Strip cropping & $\begin{array}{l}\text { A } \\
B\end{array}$ & $\begin{array}{l}58.4 \\
38.8\end{array}$ & $\begin{array}{l}91.2 \\
64.5\end{array}$ & $\begin{array}{l}66.4 \\
43.9\end{array}$ & $\begin{array}{l}74.0 \\
48.1\end{array}$ & $\begin{array}{c}134.4 \\
85.8\end{array}$ & $\begin{array}{l}196.0 \\
100.2\end{array}$ & $\begin{array}{c}142.4 \\
95.7\end{array}$ & $\begin{array}{c}157.6 \\
93.9\end{array}$ \\
\hline \multicolumn{2}{|c|}{$\operatorname{LSD}(a=0.05)$ for I $\mathrm{II}$} & 1.86 & n.s. & 4.38 & 2.17 & 9.78 & 27.40 & 11.67 & 6.50 \\
\hline \multicolumn{10}{|c|}{ Average for factors } \\
\hline SOLE CROPPING & - & 53.0 & 88.1 & 61.5 & 67.5 & 163.3 & 191.1 & 175.2 & 176.5 \\
\hline Strip cropping & - & 47.7 & 77.8 & 53.2 & 63.6 & 110.1 & 148.1 & 119.0 & 125.7 \\
\hline $\operatorname{LSD}(a=0.05)$ for I & & 3.72 & 8.98 & 2.71 & 1.99 & 9.00 & 19.40 & 7.70 & 5.10 \\
\hline- & A & 63.3 & 99.6 & 74.3 & 78.8 & 182.5 & 240.1 & 192.9 & 205.2 \\
\hline- & B & 37.4 & 66.3 & 44.9 & 49.5 & 90.9 & 99.1 & 101.4 & 97.1 \\
\hline $\operatorname{LSD}(a=0.05)$ for I & & 1.32 & 6.90 & 3.10 & 1.53 & 6.92 & 25.20 & 5.90 & 3.90 \\
\hline
\end{tabular}


Table 5

Species composition and number of weeds per $1 \mathrm{~m}^{2}$ of oat crop before harvest, depending on the cropping system (mean for 2008-2010 years)

\begin{tabular}{|c|c|c|c|c|c|c|}
\hline \multirow{2}{*}{ Species composition } & \multicolumn{3}{|c|}{ Sole cropping } & \multicolumn{3}{|c|}{ Strip cropping } \\
\hline & A & B & mean & A & $\mathrm{B}$ & mean \\
\hline \multicolumn{7}{|c|}{ Short lived } \\
\hline Echinochloa crus-galli (L) P. Beauv & 6.8 & 5.2 & 6.0 & 5.9 & 3.5 & 4.7 \\
\hline Chenopodium album $\mathrm{L}$. & 26.2 & 6.2 & 16.2 & 25.7 & 6.8 & 16.3 \\
\hline Galinsoga parviflora Cav. & 16.3 & 8.8 & 12.6 & 12.9 & 5.4 & 9.2 \\
\hline Capsella bursa-pastoris (L.) Medik. & 0.7 & 1.3 & 1.0 & - & 0.2 & 0.1 \\
\hline Galium aparine $\mathrm{L}$. & 2.6 & - & 1.3 & 1.1 & 1.3 & 1.2 \\
\hline Stellaria media (L.) Vill & 0.5 & 0.2 & 0.3 & 0.7 & - & 0.4 \\
\hline Polygonum lapathifolium L. subsp. lapathifolium & 1.0 & 0.4 & 0.7 & 0.1 & 1.0 & 0.6 \\
\hline Setaria pumila (Poir) Roem. \& Schult & 1.5 & 2.1 & 1.8 & 2.9 & 1.8 & 2.4 \\
\hline Melandrium album (Mill.) Gracke & 3.0 & 2.6 & 2.8 & 1.6 & 4.6 & 3.1 \\
\hline Thlaspi arvense $L$ & 0.8 & - & 0.4 & 0.6 & - & 0.3 \\
\hline Lapsana communis L. & 1.9 & 0.5 & 0.7 & 2.6 & 0.8 & 1.7 \\
\hline Polygonum convolvulus L. & 0.4 & 0.4 & 0.4 & 0.9 & - & 0.5 \\
\hline Avena fatua $\mathrm{L}$. & 0.5 & 0.7 & 0.6 & - & - & - \\
\hline Vicia hirsuta L. & 0.6 & - & 0.3 & 0.5 & - & 0.3 \\
\hline Myosotis arvensis L. & - & - & - & 0.9 & - & 0.5 \\
\hline Geranium pusillum L. & 0.2 & - & 0.1 & - & - & - \\
\hline Veronica arvensis L. & 0.1 & 0.3 & 0.2 & - & 0.4 & 0.2 \\
\hline Galeopsis tetrahit $\mathrm{L}$. & - & - & - & 0.8 & - & 0.1 \\
\hline Galinsoga ciliata $\mathrm{L}$. & 0.3 & - & 0.2 & - & 0.8 & 0.4 \\
\hline Viola arvensis Murray & - & 0.7 & 0.4 & 0.9 & 0.7 & 0.8 \\
\hline Setaria viridis (L.) P. Bauer. & 0.2 & - & 0.1 & - & - & - \\
\hline Anthemis arvensis L. & - & - & - & 0.4 & - & 0.2 \\
\hline Total of short-lived species & 17 & 13 & 19 & 16 & 12 & 18 \\
\hline \multicolumn{7}{|c|}{ Perennial } \\
\hline Equisetum arvense $\mathrm{L}$. & 0.2 & - & 0.1 & 0.4 & - & 0.2 \\
\hline Cirsium arvense (L.) Scop. & 1.0 & 0.4 & 0.7 & 0.6 & 0.4 & 0.5 \\
\hline Tussilago farfara $\mathrm{L}$. & 0.2 & - & 0.1 & - & - & - \\
\hline Elymus repens (L.) Gould & 0.3 & 0.2 & 0.3 & 1.6 & 0.5 & 1.1 \\
\hline Total of perennial species & 4 & 2 & 4 & 3 & 2 & 3 \\
\hline
\end{tabular}

Table 6

Weed density and air-dry weight of weeds in the oat crop

\begin{tabular}{|c|c|c|c|c|c|c|c|c|c|}
\hline \multirow{3}{*}{$\begin{array}{l}\text { I. Method of } \\
\text { cultivation }\end{array}$} & \multirow{3}{*}{$\begin{array}{l}\text { II. Weed } \\
\text { control }\end{array}$} & \multicolumn{4}{|c|}{ Weed density (per $1 \mathrm{~m}^{2}$ ) } & \multicolumn{4}{|c|}{ Air-dry weight $\left(\mathrm{g} \times \mathrm{m}^{-2}\right)$} \\
\hline & & \multicolumn{3}{|c|}{ Years } & \multirow{2}{*}{ Average } & \multicolumn{3}{|c|}{ Years } & \multirow{2}{*}{ Average } \\
\hline & & 2008 & 2009 & 2010 & & 2008 & 2009 & 2010 & \\
\hline \multirow{2}{*}{ SOLE CROPPING } & $\mathrm{A}^{*}$ & 61.1 & 62.8 & 81.4 & 68.5 & 16.0 & 40.4 & 52.1 & 68.5 \\
\hline & $\mathrm{B}$ & 10.5 & 49.4 & 36.4 & 32.1 & 5.4 & 24.8 & 9.9 & 32.1 \\
\hline \multirow{2}{*}{ Strip cropping } & A & 53.7 & 75.0 & 62.9 & 63.9 & 14.6 & 49.3 & 26.5 & 63.9 \\
\hline & $\mathrm{B}$ & 11.9 & 35.8 & 42.0 & 29.9 & 1.9 & 8.6 & 12.6 & 29.9 \\
\hline \multicolumn{2}{|c|}{$\operatorname{LSD}(a=0.05)$ for I $\mathrm{x}$ II } & n.s. & 5.97 & 2.35 & n.s. & n.s. & 1.48 & 2.58 & n.s. \\
\hline \multicolumn{10}{|c|}{ Average for factors } \\
\hline \multicolumn{2}{|l|}{ SOLE CROPPING - } & 35.8 & 56.1 & 58.9 & 50.3 & 10.7 & 32.6 & 31.0 & 50.3 \\
\hline \multirow{2}{*}{\multicolumn{2}{|c|}{$\begin{array}{l}\text { Strip cropping } \\
\operatorname{LSD}(a=0.05) \text { for I }\end{array}$}} & 32.8 & 55.4 & 52.5 & 46.9 & 8.2 & 29.0 & 19.5 & 46.9 \\
\hline & & n.s. & n.s. & 2.16 & 3.06 & 1.74 & 1.36 & n.s. & 3.06 \\
\hline \multicolumn{2}{|c|}{ A } & 57.4 & 68.9 & 72.2 & 66.2 & 15.3 & 44.9 & 39.3 & 66.2 \\
\hline \multicolumn{2}{|c|}{$\mathrm{B}$} & 11.2 & 42.6 & 39.2 & 31.0 & 3.6 & 16.7 & 11.2 & 31.0 \\
\hline \multicolumn{2}{|l|}{$\operatorname{LSD}(a=0.05)$ for II } & 4.81 & 4.22 & 1.66 & 2.36 & 1.34 & 1.05 & 8.89 & 2.36 \\
\hline
\end{tabular}

Weed control: A - mechanical, B - chemical 




Fig. 3. Air-dry weight of aboveground parts of weeds species in oats canopy (mean for 2008-2010).

\section{DISCUSSION}

Weed infestation in the maize, narrow-leafed lupin and oats crops, expressed as the number and dry weight of weeds, varied significantly in different years of the study. This was probably due to weather conditions, especially the amount and distribution of precipitation. Studies confirm the effect of temperature and the amount and distribution of precipitation on both weed density and species diversity [10].

Sekutowski and Rola [11] report that Echinochloa crus-galli and Chenopodium album are dangerous taxa in maize, as they occur frequently and are potentially harmful. Chenopodium album, Echinochloa crus-galli, Amaranthus spp, Cirsium arvense and Convolvulus arvensis also occur commonly and present a risk for maize in other parts of the world [12]. In the present study, Chenopodium album, Echinochloa crus-galli and Galinsoga parviflora were the most common taxa. These species can be considered to be dominant, as they accounted for $47.6 \%$ to $99 \%$ of the total number of weeds. Their share in the total weed biomass was also very large, from $82 \%$ to $99 \%$ in maize weeded mechanically and $38 \%$ to $58 \%$ in the treatment where herbicides were used. Among the dominant weeds in maize, Echinochloa crus-galli had the largest proportion, especially in terms of biomass. Chenopodium album, Echinochloa crus-galli and $G a$ linsoga parviflora were also the most frequent species in lupin and oats. These species are often found in various cereal crops [13,14]. Capsella bursa-pastoris, Galium aparine, Avena fatua and Polygonum convolvulus, taxa observed in lupin and other legumes, were also frequent in the lupin crop $[6,15]$.

Growing maize in wide interrows favours the use of mechanical weed control, but it is not always completely effective [16]. This is confirmed by the present study. In all years of the research, the number of weeds 
in the mechanically weeded plots was 2.5 times higher than in the treatment where herbicides were used. Even greater differences were found with respect to weed biomass. As in a study by G łow a cka [17], highly competitive species, including the uptake of macro- and micronutrients, had a large share of the total weight of weeds in maize: Echinochloa crus-galli (21.4-37.0\%), Chenopodium album (8.6-36.7\%), and Galinsoga parviflora $(8.0-18.4 \%)$.

Oats are more competitive with weeds than other crops and, according to some authors, do not need chemical weeding [18]. Where weed infestation is severe, however, herbicide use is recommended. In a study by Andruszczak et al. [19], the use of herbicides reduced the number of dicotyledonous weeds by $56.3-$ $70.2 \%$ and their biomass by $18.1-24.1 \%$ compared to double harrowing, but it increased the number of monocot weeds by $61.8-133.8 \%$. In our study, chemical weed control significantly decreased weed density in oats, by $53.2 \%$, while reducing their weight by as much as $68.3 \%$. However, weed control methods did not affect the frequency of monocot species such as Echinochloa crus-galli.

Strip cropping reduces threats from pests, diseases and weeds $[7,20]$. A study on the effects of strip cropping on weeds in maize, spring wheat and common bean found a decrease in both the number and dry weight of weeds in the bean and wheat crops compared to sole cropping [6]. In maize, however, strip cropping reduced only weed density [5]. The beneficial effects of strip cropping on the weed infestation indicators were particularly significant under mechanical weed control. Strip cropping was also found to affect the weed infestation indicators in the present study, with the nature of the changes depending on the plant species and weed control method. In recent years, much attention has been given to ecosystem biodiversity, and this applies to weeds infesting crops as well. The most commonly used measure is species diversity, expressed as the number of weed species in a community. In this study, the cropping systems did not significantly influence the number of weed species in the crops, but strip cropping decreased the share of the three dominant species - Echinochloa crus-galli, Chenopodium album and Galinsoga parviflora - in maize, oats and lupin.

\section{CONCLUSIONS}

The highest weed diversity was observed in narrow-leafed lupin, (26 taxa), while the lowest diversity in the maize crop.

The most common species in the maize, lupin and oat crops were Echinochloa crus-galli, Chenopodium album and Galinsoga parviflora. These taxa also produced the most dry matter.
Strip cropping had no effect on weed species diversity, but decreased the share of the dominant species - Echinochloa crus-galli, Chenopodium album and Galinsoga parviflora - in the total number of weeds.

Chemical weed control reduced both the number and dry weight of weeds in all crops grown in the experiment. The use of herbicides did not affect the number of species inhabiting the maize crop, but increased weed diversity in lupin and decreased it in oats.

Strip cropping significantly reduced both the number and dry weight of weeds in lupin and oats compared to sole cropping. In maize, the reducing effect of strip cropping was significant only in relation to the aboveground dry weight of weeds.

The changes observed in the number and weight of weeds show that strip cropping can affect weed infestation of crop plants. The direction and degree of change depend on the plant species, weed control method, and weather conditions during the growing season.

\section{Acknowledgements}

Research supported by the Ministry of Science and Higher Education of Poland as part of the statutory activities of the Department of Soil and Plant Cultivation, University of Life Sciences in Lublin.

\section{REFERENCES}

1. Zhang W, Ricketts TH, Kremen C, Carney K, Swinton SM. Ecosystem services and dis-services to agriculture. Ecol Econ. 2007; 64(2): 253-260. http://dx.doi. org/10.1016/j.ecolecon.2007.02.024

2. Benton TG, Vickery JA, Wilson JD. Farmland biodiversity: is habitat heterogeneity the key? Trends Ecol Evol. 2003; 18(4): 182-188. http://dx.doi.org/10.1016/ S0169-5347(03)00011-9

3. Van K. Influence of light on biomass of soybean in narrow strip cropping of oat, corn, and soybean. Korean J Crop Sci. 2002; 47(5): 368-373.

4. Liebman M, Dyck E. Crop rotation and intercropping strategies for weed management. Ecol App. 1993; 3(1): 92-122. http://dx.doi.org/10.2307/1941795

5. Głowacka A. Wpływ współrzędnej uprawy pasowej na zachwaszczenie kukurydzy pastewnej [Effect of strip intercropping system on weed infestation in maize]. Acta Agrophys. 2007; 10(3): 573-582.

6. Głowacka A. Wpływ współrzędnej uprawy pasowej na zachwaszczenie kukurydzy pastewnej [Effect of strip intercropping system on weed infestation in maize]. Acta Agrobot. 2010; 63(2): 171-178.

7. Francis C, Jones A, Crookston K, Wittler K, Goodman S. Strip cropping corn and grain legumes: a review. Americ J Alter Agric. 1986; 1(4): 159-164.

8. Ramamoorthy K, Lourduraj AC, Radhamani S, Sankaran N, Thiyagarajan TM. Effect of strip cropping and intercropping of legumes on 
productivity and economics of rainfed fingermillet. Crop Res. 2003; 26(3): 519-521.

9. Mirek Z, Piękoś-Mirkowa H, Zając A, Zając M. Flowering plants and pterdophytes of Poland. A check list [Krytyczna lista roślin naczyniowych Polski]. Cracow: W. Szafer Institute of Botany, Polish Academy of Sciences; 2002.

10. B u ra c z y ń ska D. Zachwaszczenie mieszanek owsa z łubinem wąskolistnym [Weed infestation in oats/narrow-leaf lupine mixtures]. Post Ochr Roś. 2011; 51(2): 827-831.

11. Sekutowski T, Rola H. Wpływ monokultury i systemu uprawy roli oraz ochrony herbicydowej na agrofitocenozę kukurydzy [Determination of monoculture, tillage system and herbicide application on maize agrophytocenosis]. Fragm Agron. 2010; 27(1): 128-140.

12. Baghestani M, Zand E, Soufizadeh S, Eskandari A, PourAzar R, Veysi M, et al. Efficacy evaluation of some dual purpose herbicides to control weeds in maize (Zea mays L.). Crop Prot. 2007; 26(7): 936-942. http://dx.doi.org/10.1016/j.cropro.2006.08.013

13. Sadowski T, Rychcik B. Porównanie efektów chemicznej i mechanicznej regulacji zachwaszczenia żyta ozimego [Comparison of chemical and mechanical weed control in oat]. Post Ochr Roś. 2008; 48(2): 656-659.

14. Woźniak A, Haliniarz M. The after-effect of long-term reduced tillage systems on the biodiversity of weeds in spring crops. Acta Agrobot. 2012; 65(1): 141-148. http:// dx.doi.org/10.5586/aa.2012.052

15. Gugała M, Zarzecka K. Wpływ metod uprawy roli i sposobów pielęgnacji na zachwaszczenie i plonowanie łubinu wąskolistnego odmiany Sonet [The influence of tillage methods on weed infestation and yielding of narrow-leaf lupin cultivar Sonet]. Fragm Agron. 2012; 29(1): 16-24.

16. Abdin OA, Zhou XM, Cloutier D, Coulman DC, Faris MA, Smith DL. Cover crops and interrow tillage for weed control in short season maize (Zea mays). Eur J Agron. 2000; 12(2): 93-102. http://dx.doi.org/10.1016/ S1161-0301(99)00049-0

17. G łowacka A. Dominant weeds in maize cultivation and their competitiveness under conditions of various methods of weed control. Acta Agrobot. 2011; 64(2): 27-34.

18. Idziak R, Michalski T, Osiecka B. Weed infestation and yielding of spring barley - oats mixtures under differentiated plant protection conditions. Zesz Probl Post Nauk Rol. 2007; 516: 55-63.

19. Andruszczak S, Kwiecińska-Poppe E, Kraska P, Pałys E. The effect of different agrotechnical levels on weed infestation in crops of naked and husked varieties of oat (Avena sativa L.). Acta Agrobot. 2010; 63(2): 207-213.

20. Carruthers K, Fe Q, Cloutier D, Smith DL. Intercropping corn with soybean, lupin and forages: weed control by intercrops combined with interrow cultivation. Eur J Agron. 1998; 8(3-4): 225-238. http://dx.doi.org/ $10.1016 /$ S1161-0301(97)00062-2

\section{Wpływ uprawy pasowej i metod regulacji zachwaszczenia na różnorodność chwastów w kukurydzy pastewnej (Zea mays L.), owsie siewnym (Avena sativa $\mathrm{L}$.) i łubinie wąskolistnym (Lupinus angustifolius L.)}

\section{Streszczenie}

Doświadczenie przeprowadzono w latach 2008-2010 w Stacji Doświadczalnej Wydziału Nauk Rolniczych, Uniwersytetu Przyrodniczego w Lublinie. Schemat badań obejmował dwa czynniki: I. Metoda uprawy - siew czysty i uprawa pasowa, polegająca na uprawie w sąsiadujących ze sobą pasach o szerokości 3,3 m trzech roślin: kukurydzy pastewnej, łubinu wąskolistnego i owsa siewnego; II. Metoda regulacji zachwaszczenia - mechaniczna i chemiczna Przedmiotem badań było zachwaszczenie kukurydzy pastewnej odmiany 'Celio', łubinu wąskolistnego odmiany „Sonet” i owsa siewnego odmiany 'Kasztan'. Zachwaszczenie roślin określano dwa tygodnie przed zbiorem, metodą botaniczno-wagową, określając skład florystyczny i liczebność poszczególnych gatunków chwastów oraz ich powietrznie suchą masę.

Największą różnorodność chwastów stwierdzono z zasiewach łubinu wąskolistnego, najmniejszą zaś w kukurydzy pastewnej. Gatunkami dominującymi w zachwaszczeniu kukurydzy, łubinu wąskolistnego i owsa siewnego były Echinochloa crus-galli, Chenopodium album oraz Galinsoga parviflora stanowiące od $34,1 \%$ do $99 \%$ ogólnej liczby chwastów. Uprawa pasowa wyraźnie zmniejszała liczbę chwastów na jednostce powierzchni w zasiewach łubinu wąskolistnego i owsa siewnego oraz wytworzoną przez nie sucha masę części nadziemnych we wszystkich uprawianych gatunkach. Chemiczna metoda regulacji zachwaszczenia zmniejszała istotnie zarówno liczbę jak i masę chwastów w porównaniu z metodą mechaniczną.

Handling Editor: Elżbieta Weryszko-Chmielewska

This is an Open Access digital version of the article distributed under the terms of the Creative Commons Attribution 3.0 License (creativecommons.org/licenses/by/3.0/), which permits redistribution, commercial and non-commercial, provided that the article is properly cited.

CThe Author(s) 2013 Published by Polish Botanical Society 